Volume 3 Issue 1, March 2019: pp. 103-115. Copyright (c) 2019 HOLREV. Faculty of Law, Halu Oleo University, Kendari, Southeast Sulawesi, Indonesia. ISSN: 2548-1762 | e-ISSN: 2548-1754. Open Access at: http://ojs.uho.ac.id/index.php/holrev/

Halu Oleo Law Review is licensed under a Creative Commons Attribution 4.0 International License, which permits unrestricted use, distribution, and reproduction in any medium, provided the original work is properly cited.

\title{
Konsensus dan Sikap Para Ulama Salaf Kontemporer dalam Melawan Terorisme dan ISIS
}

\section{Consensus and Attitudes of Contemporary Scholars of the Salafin the Fiht Against Terrorism and ISIS}

\author{
Sukring \\ Dosen Pendidikan Agama Islam \\ Fakultas Hukum Universitas Halu Oleo \\ E-mail: sukring_69@yahoo.co.id
}

\begin{abstract}
The tragedy of terrorism and ISIS has enormous destructive power. All madzahab jurisprudence and scholars of the salaf contemporary firmly and clearly, emphatically and clearly stated in many their opinion, that which justifies the killing of muslims are infidels and consider them as khawarij, so for the terrorists with characteristics similar effect in khawarij, acts of terror and murder in many of the arguments of al-Qur'an and traditions is strictly prohibited andreferred a great sin. Terror and violence in the concept of Islam is not justified is not single thought and scholars of Islam tolerate either outside or inside Islam itself. Lately terror in the name of Islam began to spread back often emergence of goups extreme/hard perform on behalf of the movement establish an Islamic state or want to restore the past glory of Islam, namely to establish the Khilafah Islamiyah (ISIS). The attitude of the scholars of the salaf emphatically that Islam must be based on rational arguments on establishing a state order. The majority of scholars reject the violence and terror in all activities in the name of Islam.
\end{abstract}

Keyword: Consensus; Ulama Salaf; terrorism; ISIS

Abstrak: Tragedi Terorisme dan ISIS memiliki daya rusakyang sangat besar. Semua
madzhab fiqih dan para ulama salaf kontemporer secara tegas dan jelas telah
menyatakan di banyak pendapat mereka, bahwa yang menghalalkan pembunuhan
terhadap muslim adalah kafir dan menganggap mereka sebagai khawarij, sehingga
bagi para pelaku teror dengan ciri-ciri yang sama diberlakukan tindakan-tindakan
yang diperlukan seperti tindakan yang diberlakukan pada khawarij. Tindakan teror
dan pembunuhan dalam banyak dalil-dalil Al-Qur'an dan hadis sangat di larang dan
termasuk dosa besar. Teror dan kekerasan dalam konsep Islam tidak dibenarkan
tidak satu pemikir dan ulama pun yang menolerir baik di luar Islam maupun dalam
tubuh Islam sendiri. akhir-akhir ini teror yang mengatasnamakan Islam mulai 
merebak kembali seiring munculnya kelompok-kelompok ekstremis/keras yang melakukan atas nama gerakan mendirikan Negara Islam atau ingin mengembalikan kejayaan Islam di masa lampau yaitu penegakan Khilafah Islamiyah (ISIS). Sikap para ulama salaf tegas bahwa Islam harus berlandaskan argumen yang rasional dalam mendirikan suatu tatanan kenegaraan. Ulama mayoritas menolak adanya kekerasan dan teror dalam segala aktivitas yang mengatasnamakan Islam.

Kata kunci: Konsensus; Ulama Salaf; Terorisme; ISIS

\section{PENDAHULUAN}

Aksi terorisme yang akhir-akhir ini sering terjadi, bahkan dalam jangka waktu yang berkala sepanjang tahunya, khususnya di Indonesia dan umumnya di belahan dunia. Selalu dikaitkan dengan Islam dan kaum muslimin. Ketika sebuah bom meledak sehingga menewaskan atau melukai banyak orang serta merusak berbagai fasilitas, maka dengan sigap ujung jari telunjuk langsung diarahkan kepada Islam. Isu yang mengidentikkan bahwa Islam adalah teroris dan teroris adalah Islam mulai muncul ke permukaan bahkan menjadi opini global, setelah kejadian 11 September 2001. Presiden Amerika serikat pada saat itu menuduh pelakunya adalah jaringan Al-Qaida pimpinan Osama Bin Laden. Sehingga kemudian memetakan dunia ke dalam 2 (dua) bagian yang berseberangan yaitu Islam sebagai teroris dan Amerika sebagai pembasmi teroris.

Di Indonesia sendiri telah terjadi serangkaian aksi terorisme. Orang-orang yang melakukan aksi terorisme di Indonesia mengklaim bahwa kasinya itu adalah jihad melawan Amerika. Apakah benar demikian semangat yang di bangun dan tujuan yang hendak dicapai? Jihad dalam ajaran Islam memiliki konsep yang jelas dan memiliki tujuan yang jelas pula. Oleh karena itu tokoh-tokoh Islam, para ahli intelijen, dan pemerhati terorisme menilai bahwa aksi terorisme yang terjadi di Indonesia merupakan sebuah rekayasa dan konspirasi yang sengaja dipelihara oleh pihak-pihak tertentu untuk kepentingan-kepentingan tertentu pula.

Rekayasa dan konspirasi tersebut dijalankan secara sistematis sehingga faktanya jelas dengan adanya upaya infiltrasi ke dalam kelompok Islam yang memiliki semangat perlawanan terhadap kemungkaran dengan teknik dan pengelabuan informasi mereka dibuat radikal atau lebih radikal dengan doktrin jihad yang menyimpang. Tidak kalah dengan munculnya sebuah konspirasi yang menamakan dirinya ISIS. ISIS mengklaim dirinya sebagai kekuatan baru yang akan mengganti kekuasaan dunia Islam dengan kekuasaan Khilafah Islamiyah. Sepak terjang ISIS ini semakin tak terkendali dengan 
kejahatan yang dilakukan. Sehingga masyarakat dunia mengecam dan mengutuk segala tindakannya yang semakin tidak manusiawi itu. ISIS adalah organisasi pemberontak terhadap Negara muslim dan ingin mengganti sistem pemerintahan dan otoritasnya, sehingga pemberontakan ISIS adalah bertentangan dengan hukum Islam.

Dalam tulisan ini akan dikemukakan konsep pemikiran ulama salaf Kontemporer dan empat mazhab yang berkaitan dengan terorisme dan ISIS yang merebak kembali di dunia dan semakin menunjukkan identitas Islam. Padahal teror dan perilaku ISIS hanya dilakukan oleh segelintir umat Islam yang kemudian menjadikan citra Islam semakin tertekan, tertindas dan terpuruk dalam kancab dunia Internasional.

\section{ANALISIS DAN PEMBAHASAN}

\section{Pengertian Terorisme}

Sebelum mendiskusikan tentang terorisme, kita harus tahu dan paham tentang definisi dari teror itu sendiri. Teror secara etimologi berasal dari kata "terrour" (Inggris Tengah), "terreur" (Perancis lama), "terror" (Latin) dan "terre" (Latin), yang artinya adalah untuk menakuti. Definisi teror menurut beberapa ensiklopedia dan kamus: sangat takut, sangat ketakutan suatu emosi yang dialami sebagai antisipasi dari suatu rasa sakit atau bahaya (biasanya disertai oleh suatu keinginan untuk kabur atau untuk melawan) rasa panik atau perasaan yang sangat tidak tenang sifat yang sangat menyusahkan, terutama pada anakanak.

Dalam Bahasa Arab, terorisme dikenal dengan istilah Al-Irhab. Dari sini, bisa dipahami bahwa kata Al-Irhab (teror) berarti (menimbulkan) rasa takut. Irhabi (teroris) artinya orang yang membuat orang lain ketakutan, orang yang menakut-nakuti orang lain. Sedangkan dalam Kamus Besar Bahasa Indonesia, terorisme adalah puncak aksi kekerasan, terrorism is the apex of violence. ${ }^{1}$

Konsep teror adalah al-irhâb (irhâbiyyah), al-hirâbah (perampokan), al-baghy (pemberontakan), qâthi 'al-tharîq atau quththâ' al-tharîq (pembajakan), dan al-'unf (sebuah antonim dari kelemah-lembutan). Tindakan yang dimaksudkan dalam konsep tersebut dikategorikan sebagai terorisme karena kekerasan yang ditimbulkannya, menyebabkan kepanikan orang, kerusakan material dan fisik, dan memiliki tujuan politik. Aksi teror semacam itu, bahkan jika mereka berkomitmen berdasarkan pada tatanan Jihad,

1 Abdul Zulfidar Akaha, Terorisme Konspirasi Anti Islam, Jakarta: Pustaka Al-Kautsar, 2005. 
seperti pembunuhan, pembajakan, pemboman, perampokan dan intimidasi dilarang dan tidak dapat dilegitimasi karena bertentangan dengan ajaran Islam yang melarang tindakan merusak di bumi, ke prinsip al-dlarûriyyât al-khams (melestarikan lima kebutuhan dasar manusia), kemanusiaan, keadilan dan pertimbangan dalam Islam. ${ }^{2}$

Selain itu, ada beberapa definisi tentang terorisme antara lain:

1. Menurut Konvensi PBB tahun 1937, terorisme adalah segala bentuk tindak kejahatan yang ditujukan langsung kepada negara dengan maksud menciptakan bentuk teror terhadap orang-orang tertentu atau kelompok orang atau masyarakat luas.

2. Menurut US Federal Bureau of Investigation (FBI), terorisme adalah penggunaan kekuasaan tidak sah atau kekerasan atas seseorang atau harta untuk mengintimidasi sebuah pemerintahan, penduduk sipil dan elemenelemennya untuk mencapai tujuan-tujuan sosial atau politik. ${ }^{3}$

3. Menurut Muhammad Mustofa, terorisme adalah tindakan kekerasan atau ancaman kekerasan yang ditujukan kepada sasaran secara acak (tidak ada hubungan langsung dengan pelaku) yang berakibat pada kerusakan, kematian, ketakutan, ketidakpastian dan keputusasaan massal. ${ }^{4}$

Jadi kesimpulannya dari beberapa definisi di atas, terorisme merupakan suatu cara untuk mencapai tujuan tertentu dengan menggunakan ancaman kekerasan guna menimbulkan rasa takut dan menjatuhkan korban sebanyak-banyaknya secara tidak beraturan.

\section{Pendapat Ulama Salat Kontemporer Tentang Terorisme dan ISIS}

Terorisme adalah Khawarij di era kita. Ulama salaf yang terkenal di dunia Arab, syaikh Muhammad Nashir Al-Din Al-Albani menjelaskan pandangannya mengenai teroris dan ISIS dalam artikel berikut ini.

Yang dimaksud adalah bahwasanya mereka adalah orang-orang yang melakukan tradisi jahat di dalam Islam. Mereka menjadikan pembelotan dari imam sebagai doktrin agama dari generasi ke generasi. Telah banyak peringatan Nabi atas bahaya mereka di dalam sejumlah hadist, di antaranya adalah sabdanya "khawarij adalah

2 Kasjim Salenda, “Terorisme dalam Perspektif Hukum Islam”, Ulumuna, Volume XIII, Nomor 1, Juni 2009, hlm. 81.

3 Muladi, Demokrasi HAM dan Reformasi Hukum di Indonesia, Jakarta: RajaGrafindo, 2002, hlm. 172.

4 Muhammad Mustofa, "Memahami Terorisme: Suatu Perspektif Kriminolog", Jurnal Kriminologi Indonesia, Jakarta: FISIP UI, 2002. 
anjing-anjing neraka." Berdasarkan pula pada ketidakjelasan kekafiran mereka, karena mereka sebatas melakukan kezaliman, kedurhakaan, dan kefasikan. ${ }^{5}$

Hari ini sejarah berulang. Muncul generasi muda muslim yang tidak memahami agama dengan sebenarnya. Mereka berpendapat bahwa banyak para pemangku pemerintahan yang tidak menjalankan hukum Allah kecuali hanya sedikit saja (yang menjalankan hukum Allah) maka mereka berpikir untuk membelot dari pemerintahan tanpa meminta pendapat dari para ulama dan ahli fiqih atas orang-orang bijak di kalangan mereka. Bahkan mereka mengikuti pemimpin-pemimpin mereka yang mendapatkan fitnah (kekerasan) secara membabi buta dan menumpahkan darah Mesir, Suriah dan Aljazair serta melakukan kekacauan sebelumnya di tanah suci Mekah. dengan demikian mereka telah menantang hadits shahih yang di amalkan oleh umat Islam dahulu dan sekarang kaum khawarij. ${ }^{6}$

Orang yang menganggap muslim sebagai kafir adalah tanda Khawarij. Dalam website resminya Syaikh Abdullah bin Abdulah bin Bas mantan mufti agung Saudi Arabia, pernah ditanya "kita tahu bahwa kata-kata ini merupakan representasi dari dasar yang mendasari orang-orang Sunni. Akan tetapi, sayang ada beberapa pemuda dari kalangan Ahlu sunnah wal Jamaah yang mempercayai bahwa Ushul (dasar fundamental) ini merupakan sikap mental kalah dan pengecut. Ideologi ini tentu saja telah di ekspresikan dan memberikan semacam kekuatan kepada mereka mengadopsi kekerasan dalam proses perubahan.

Syaikh bin Baz menjawab: ini adalah kekeliruan dan kadang kalah pemahaman orang yang berpendapat seperti itu. Hal ini dikarenakan mereka memahami sunah tidak sebagaimana mestinya. Mereka hanya berbekal semangat untuk melenyapkan kemungkaran sehingga tergelincir kepada hal yang bertentangan dengan syariat sebagaimana yang dilakukan khawarij mereka hanya berbekal semangat untuk menegakkan kebenaran yang justru menjerumuskan mereka kepada kebatilan sehingga mereka berani mengkafirkan umat Islam hanya karena perbuatan maksiat mereka sebagaimana yang telah dilakukan orang-orang khawarij. Orang-orang khawarij-lah yang

5 Muhammad Tahir ul-Qadri. Fatwa Tentang Teorisme dan Bom Bunuh Diri. Cet. L. Minhaj-ul-Quran Internasional, 2010, hlm. 273.

6 Muhammad Nashir Al-Din Al-Bani dalam silsilah Al-Ahaīis Al-Shahīhah. Riyadh: Dra Al-Wathan, 1999, hlm. 1240-1243. 
telah menganggap kafir orang-orang yang melakukan maksiat karena perbuatan maksiatnya dan menganggap mereka akan kekal di neraka. ${ }^{7}$

Sementara itu pendapat Ahlu al-Sunnah yang benar adalah bahwa orang yang melakukan maksiat tidaklah menjadi kafir karena maksiatnya sepanjang tidak menganggap halal kemaksiatannya. Apabila dia berzina, mencuri, dan minum khamr (arak atau yang sejenisnya) maka semua hal ini tidak membuatnya menjadi kafir. Orang yang melakukan maksiat itu (dicap) sebagai orang yang imannya lemah dan menjadi orang yang fasik yang harus diperlakukan atasnya sanksi hukum. Dia tidak di anggap kafir jika dia telah menghalalkan kemaksiatan itu dengan mengatakan "ini halal” pendapat khawarij mengenai hal ini adalah pendapat yang batil. Pengkafiran mereka terhadap orang lain adalah batil. Mengenai mereka nabi pernah bersabda "sesungguhnya mereka belum keluar dari agama kecuali seperti lepasnya anak pana dari busurnya kemudian mereka tidak bisa kembali lagi kepadanya (agama Islam). Mereka memerangi umat Islam tapi membiarkan para penyembah berhala.

Inilah kondisi kaum khawarij disebabkan oleh sikap ekstrem, kebodohan dan kesesatan mereka. Maka tidak pantas bagi kaum muda dan tua mengikuti kaum khawarij. Mereka justru harus mengikuti mazhab Ahlu Sunah wal-Jamaah yang berdasarkan konteks dalil-dalil syariah. Mereka menerima teks sebagaimana adanya. Mereka tidak membelot dari Sulthan (imam) karena satu dan sejumlah kemaksiatan yang dilakukannya. Mereka bahkan menyampaikan nasehat melalui tulisan dan dialog dengan cara yang baik dan bijaksana serta ada argumentasi dengan cara yang lebih baik sehingga mereka pun selamat dan kejahatan pun berkurang atau hilang serta kebaikan pun menyebar.

Teroris dan ISIS hari ini adalah kelompok masyarakat bodoh. Ulama salaf dari arab Saudi yang terkenal Syaikh Shalih al-Fausan pernah ditanya" beberapa orang pernah berkata bahwa pemerintah dan ulama telah menghalangi jihad yang berarti sama dengan menantang perintah Allah bagaimana pendapat Anda mengenai hal ini? Dia menjawab

"ini adalah pendapat orang bodoh yang menunjukkan bahwa dia tidak memiliki kebijakan dan ilmu, sehingga dia mengafirkan orang lain. Ini adalah pemikiran kaum khawarij dan mu'tazilah kita memohon keselamatan kepada Allah. Akan tetapi kita tidak mau berburuk sangka kepada mereka. Kita hanya berpendapat bahwa mereka adalah orang-orang bodoh. Mereka wajib belajar sebelum berpendapat. Jika mereka berilmu dan berpendapat seperti itu maka ini adalah pemikiran khawarij dan orang-orang sesat."

Muhammad Tahir Ul-Qadri, op. cit., hlm. 174.

8 Shalih Al-Fauzan. Al-Jihād wa Dhawabituhu Al-Syariyyah., tt., hlm. 49. 
"Maha Suci Allah, kelompok ini tetap eksis. Bukankah itu aksi adalah aksi kaum khawarij yaitu mengafirkan umat Islam dan meneror mereka.Ini adalah madzab khawarij, yaitu yang berpijak pada tiga perkara. Pertama, mengkafirkan umat Islam. Kedua, membelot dari ketaatan kepada pemerintah ketiga, menghalalkan darah umat Islam.ini merupakan madzab khawarij sekalipun hanya di yakini oleh hati dan tidak mengamalkannya. Dia telah menjadi seorang khawarij dalam akidah dan pemikirannya yang tidak dia ucapkan." 9

Pandangan tersebut di atas, memberikan pemahaman bagi seluruh kaum Muslimin bahwa kelompok yang mengatasnamakan Islam dalam kegiatan terorisme dan pembangkangan terhadap pemerintah yang sah (ISIS) merupakan pembelotan akidah Islamiyah. Sebagaimana pendapat di atas yang memberikan ciri-ciri kelompok yang menjustifikasi kegiatan mereka sebagai jihad, padahal mereka telah melakukan kejahatan terorisme, dan terorisme merupakan perbuatan yang dilarang oleh agama Islam.

Terorisme bukan jihad, berbicara tentang jihad, mufti Nadzir Husain al-Dihlawi, salah seorang ulama salaf di bidang hadis di anak benua India ini, dia pernah menulis "akan tetapi akan banyak syarat untuk jihad. Sehingga syarat tersebut belum dipenuhi, maka aktivitas itu tidak bisa di sebut jihad. Pertama, harus ada penguasa muslim. Dalil mengenai hal ini disebutkan dalam Al-Qur'an ketika Allah menjelaskan salah satu kisah Nabinya di zamannya lalu yang umatnya meminta kepada Nabi mereka supaya diutus penguasa atau komandan yang menyerukan jihad, 10

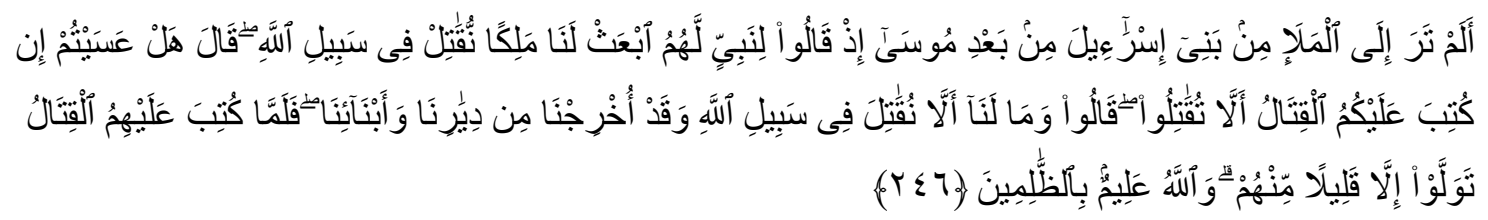

Terjemahnya: "Tidakkah kamu perhatikan para pemuka Bani Israil setelah Musa wafat, ketika mereka berkata kepada seorang nabi mereka." Angkatlah seorang raja untuk kami, niscaya kami berperang di jalan Allah." Nabi mereka menjawab, "Jangan-jangan jika diwajibkan atasmu berperang, kamu tidak akan berperang juga?" Mereka menjawab, "Mengapa kami tidak akan berperang di jalan Allah, sedangkan kami telah diusir dari kampung halaman kami dan (dipisahkan dari) anak-anak kami?" Tetapi ketika perang itu diwajibkan atas mereka, mereka berpaling, kecuali sebagian kecil dari mereka. Dan Allah Maha Mengetahui orangorang yang zalim." (Q.S. 2:246).

Ayat ini menjelaskan bahwa jihad tidak bisa dilakukan tanpa seorang penguasa. Sebab bisa dilakukan tanpa penguasa mereka, maka mereka tidak akan mengungkapkan

9 Farid Al-Husain, Al-Fatawa Al-Syariyyah fi Al-Qadhaya Al-Ashriyyah, Beirut: Dar Ihya Al-Turats Al-Arabi, tt, hlm. 76.

10 Muhammad Tahir Ul-Qadri., op. cit., hlm. 277. 
kata-kata tersebut. Dan telah disebutkan dalam sebuah hadis bahwa pemimpin itu adalah pelindung dan seorang harus berperang serta menyelamatkan nyawanya di balik pelindung tersebut. Abu Hurairah ra. meriwayatkan bahwa Rasulullah saw. bersabda:

$$
\text { انما الامام جنة يقال من ور ائه ويتقى بـ }
$$

Artinya: "sesungguhnya iman itu adalah banteng berperang di belakangnya dan dijadikan tameng (iman berada digaris depan)" (H.R. Bukhari Muslim). ${ }^{11}$

Hadis ini secara jelas menyebutkan bahwa jihad hanya dapat digelorakan oleh seorang penguasa. Kedua, harus ada logistik dan alat perang yang cukup untuk mendukung jihad melawan musuh dalam medan peperangan Allah berfirman dalam AlQur'an.

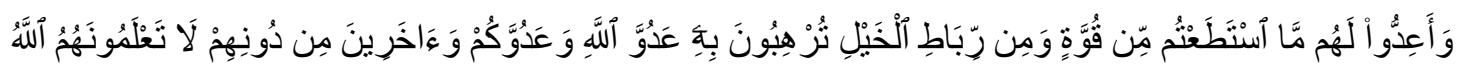

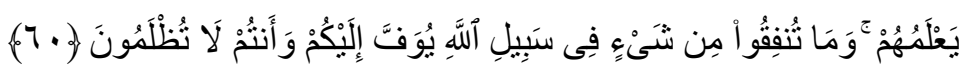

Terjemahnya: "Dan persiapkanlah dengan segala kemampuan untuk menghadapi mereka dengan kekuatan yang kamu miliki dan dari pasukan berkuda yang dapat menggentarkan musuh Allah, musuhmu dan orang-orang selain mereka yang kamu tidak mengetahuinya; tetapi Allah mengetahuinya. Apa saja yang kamu infakkan di jalan Allah niscaya akan dibalas dengan cukup kepadamu dan kamu tidak akan dizalimi (dirugikan)." (Q.S. 8: 60).

Imam Al-Baghawi berkata ketika menafsirkan ayat ini;

$$
\text { الاعداد الثئ بوقت الحاجة من قوة ائ من الا الات التى نكون اكم قوة عليهم من الخيل و السلاح }
$$

Persiapan itu adalah pengambil sesuatu yang dibutukan berupa kekuatan yaitu alat-alat yang menjadikan kekuatan bagi kalian untuk melawan musuh berupa kuda dan persenjataan.

Allah swt. dalam firman-Nya. (Q.S./ 4:71)

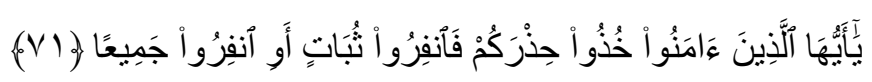

Terjemahnya: Wahai orang-orang yang beriman! Bersiap siagalah kamu, dan majulah (ke medan pertempuran) secara berkelompok, atau majulah bersamasama (serentak).

Ahli hadis dan pergerakan sunah berpendapat dalam menafsirkan ayat ini," dalam kata lain, persiapan dan persenjataan militer." Hadis ini menjelaskan makna yang sama pada kita. Hal ini merupakan bukti jika jihad tidak bisa dilaksanakan tanpa persenjataan yang lengkap.

11 Al-Bukhāri dalam Al-Jami Al-Shahih, Beirut: Dar Ibnu Katsir, 1987. Kitab Al-Jihād wa Al-Siyār,. Bab Imam Adalah perisai; Berperang Membelanya dan Meminta perlindungan. 3;1080 hadis ke 2797; Muslim dalam Al-Shahih; kitab Al-Imarah; Bab Imam Adalah Perisai Berperang Membelanya dan Meminta Perlindungannya, 3;1080 hadis ke 2797. 
Ketiga, harus ada benteng, Negara, atau blok keamanan yang menjadi harapan perlindungan kaum muslim. Berdasarkan kata "kekuatan", Ikrima berkata, "kekuatan" berarti "benteng". Hal ini disebutkan oleh al-Baghawi dalam Ma'alim al-tanzil. Jihad tidak diwajibkan kecuali setelah Nabi Muhammad saw. hijrah ke Madinah dan menjadi pusat perdamaian yang menentramkan. Hal ini sangat jelas bahwa mujahid harus punya tempat yang dapat menjadi benteng keamanan.

Keempat, Muslim harus memiliki prajurit yang cukup untuk berperang melawan pasukan kafir. Paling tidak jumlahnya adalah dari kekuatan musuh. Allah berfirman:

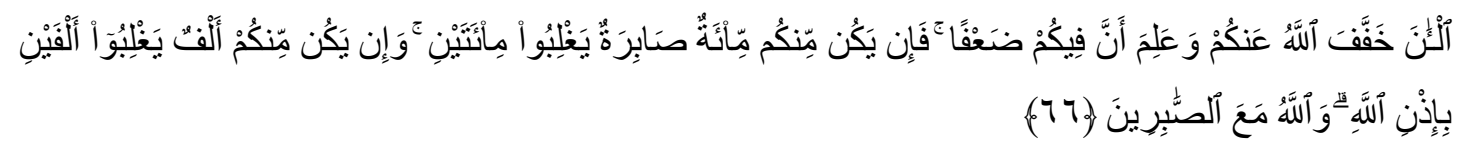

Terjemahnya: Sekarang Allah telah meringankan kamu karena Dia mengetahui bahwa ada kelemahan padamu. Maka jika di antara kamu ada seratus orang yang sabar, niscaya mereka dapat mengalahkan dua ratus (orang musuh); dan jika di antara kamu ada seribu orang (yang sabar), niscaya mereka dapat mengalahkan dua ribu orang dengan seizin Allah. Allah beserta orang-orang yang sabar.(Q.S. 8: 66).

Ayat ini dengan secara jelas menyatakan bahwa muslim harus berperang dengan rasio satu banding dua, tidak lebih dari itu. Menurut hemat penulis, tidak ada satu syarat jihad pun yang terpenuhi hari ini. Sebab jihad, tidak mungkin di tegakkan, kecuali dengan syarat-syarat ini.

$$
\text { ان انس ان رسول الله صا الله عليه وسلم قال، لكل غادر لو اء يوم القيامة يعرو بـا }
$$

Artinya; "Dari Anas, sesungguhnya Rasulullah bersabda, "bagi setiap penghianat akan mendapatkan bendera pada hari kiamat yang menjadi (tanda) pengenalnya."(H.R. Bukhari muslim).

\section{Fatwa Empat Imam Mazhab tentang Terorisme}

Imam Abū Hanifah berkata dalam bukunya, Al-Figh Al-Absath, berkaitan dengan perlawanan terhadap para teroris. Perangilah para pembelot, bukan karena kekufuran mereka. Bergabunglah bersama kelompok yang adil dan jangan bergabung bersama para pembelot. Sekalipun di dalam jamaah itu terdapat kelompok yang suka berbuat zalim dan kerusakan, maka sesungguhnya di kalangan mereka juga terdapat orang-orang saleh yang akan membantu kalian memerangi mereka. Jika jamaah itu melakukan pembelotan juga, maka menjauhlah dari mereka dan pindahlah ke jamaah lain. Allah berfirman, "bukankah 
bumi Allah swt. itu luas, sehingga kamu dapat berhijrah di bumi itu, sungguh bumi-Ku luas, maka sembahlah Aku (saja). ${ }^{12}$

Pendapat tersebut, harus dipahami bahwa persatuan umat Islam menjadi urgen dalam kehidupan, Islam melarang untuk keluar dari jamaah apalagi sampai melakukan makar, sehingga mereka yang melakukan makar, maka harus di perangi. Demikian imam Saḩrūn menulis dalam Al-Mudawwanah, mengenai perkataan imam Mālik. Imam Mālik berkata mengenai kelompok Ibhadiyah, Haruriyah, dan semua pengikut hawa nafsu, "Aku berpendapat bahwa mereka harus diajak untuk bertobat. Jika mereka bertobat, maka mereka dibiarkan dan jika menolak mereka harus diperangi." Ibnu Al-Qāsim berkata, mengenai kelompok haruri dan sejenisnya. Imam Mālik berkata mereka diperangi jika tidak mau bertobat dan jika imam bersikap adil ini menunjukkan kepada Anda bahwa jika mereka membelot dari imam yang adil dan juga bermaksud memeranginya serta mengajak kepada kelompok mereka, maka mereka terlebih dahulu harus terlebih diajak kembali kepada jamaah, jika mereka menolak, maka mereka harus diperangi. Ibnu AlQāsim berkata lagi. sungguh aku telah bertanya kepada Imam Mālik mengenai kelompok yang melakukan maksiat yang berada di Syam, bahwa imam harus mengajak mereka kembali dalam jamaah dan menegakkan keadilan di antara mereka. Jika mereka mau kembali, maka mereka harus dibiarkan dan jika tidak, maka mereka harus diperangi.13

Para terorisme dan ISIS adalah kelompok pembelot, jika mereka diajak bertobat, kemudian mereka bertobat, maka mereka dibiarkan, tetapi jika mereka tidak mau bertobat, maka memeranginya adalah wajib hukumnya. Demikian juga tentang terorisme imam Syāfi'i berkata jika ada suatu kaum (sekumpulan umat manusia) baik di perkotaan maupun di pedalaman padang pasir, kemudian mereka menumpahkan darah dan merampas harta, maka mereka di hukum dengan perampok. Sama saja apakah pembangkangan itu dilakukan di perkotaan ataupun di pedalaman. Akan tetapi yang lebih besar bahayanya adalah pembangkangan yang dilakukan di perkotaan. ${ }^{14}$

Jika para pembuat keonaran menolak ajaran kembali, maka perangilah mereka itu. Kelompok bughā (teroris) itu boleh diperangi jika mereka memerangi. Mereka tidak disebut memerangi kecuali apabila melakukan perlawanan, pembangkangan dan kudeta. Ketika semua itu dilakukan oleh mereka, maka mereka tidak dalam keadaan boleh

\footnotetext{
12 Abū Hुanifah, Al-Figh Al-Absath, Zāhid Al-Kausar dalam Majmū Al-Aqidah wa 'lim Al-kalām, hlm. 606-607, lihat QS.Al-Ankabūt/29: 56.

13 Sahrūn, Al-Mudawwamah Al-Kubrā,tt., hlm. 3: 94.

14 Al-Syāfi'i, Muhammad bin Idris, Al-Umm, Beirut: Dār Al-kutub Al-Ilmiyyah, tt., hlm. 4: 218.
} 
diperangi. Darah mereka terjaga seperti sebelum mereka menjadi pembelot sepanjang mereka tidak keluar dari hal-hal di atas. ${ }^{15}$

Selanjutnya, Abū Al-Ḩārits meriwayatkan bahwa ia pernah bertanya kepada imam Ahmad bin Hambal tentang pemberontakan terhadap pemerintah yang terjadi di Baghdad. Pada saat itu penguasa Abbāsiyah berada di bawah pengaruh kuat orang-orang mu'tazilah. Mereka telah menciptakan bahaya serius terhadap umat Islam secara umum. Akan tetapi, ketika imam Ahmad di minta untuk bergabung ke dalam fron pemberontak untuk melawan pemerintah zalim, ia berkata "Subhānallah, darah, darah. Aku tidak berpendapat boleh menumpahkan darah dan tidak pula memerintahkannya. Bersikap sabar dengan kondisi yang ada daripada terjadi fitnah yang menimbulkan pertumpahan darah, dihalalkannya merampas harta dan dinodainya kehormatan. ${ }^{16}$

Beberapa orang masih memaksa dan berkata, bukankah kita diwajibkan berjihad untuk melawan kezaliman ini? Mendengar hal itu, imam Ahmad menjawab, tentu saja, kekacauan ini akan berakhir pada waktunya. Akan tetapi, jika pedang telah dihunuskan, pembunuhan adalah hasilnya dan pintu damai serta kemaslahatan akan tertutup.

Ketika pemberontakan menemukan momentumnya pada zaman khalīfah Al-Watsīq Billāh, para fuqaha bersama-sama menghadap imam Ahmad dan melaporkan situasi yang semakin memburuk. Imam Ahmad balik bertanya kepada mereka tentang apa yang mereka inginkan. Kemudian mereka mengutarakan bahwa kedatangan mereka adalah untuk mencari bimbingan dan nasehat, karena sikap pemerintah semakin memuakkan. Para fuqaha ini ingin bergabung dalam fron pemberontakan untuk menggulingkan kekuasaan Khaliffah. Kemudian imam Ahmad menasihati mereka agar tetap bersabar. Kemudian imam Ahmad berkata, meski situasi semakin memburuk, dari sekarang kalian harus mengubah pikiran kalian dan jangan pernah ingin melawan otoritas pemerintah. Lanjut imam Ahmad berkata; kalian wajib mengingkari dengan hati, tetapi jangan melakukan pembangkangan, jangan memecah belah persatuan umat Islam. Jangan menumpahkan darah kalian dan darah umat Islam bersama kalian. Perhatikan akibat keputusan kalian. Bersabarlah hingga orang baik beristirahat dan merasa aman dari orang jahat. Jangan melakukan pembelotan karena bertentangan dengan hadis-hadis yang menyuruh kita agar bersabar. ${ }^{17}$

\footnotetext{
15 Ibid.

16 HR. Al-Khalā dalam Al-Sunan, h. 132 hadis ke-89 riwayat ini disampaikan dengan sanad yang sahih.

17 Ibid., hlm. 133, hadis ke-90.
} 


\section{KESIMPULAN}

Berdasarkan Al-Qur'an dan as-Sunah, pendapat para ahli fiqh dan hukum, penjelasan para ulama hadis serta mufti-mufti, bahwa pemberontak (terror) adalah mereka yang berinisiatif untuk memberikan perlawanan bersenjata kepada kebijakan muslim dan memiliki kemampuan untuk melakukannya. Mereka menolak mengakui pemerintahan yang sah, serta mendeklarasikan diri melawan pemerintah dengan mengangkat senjata tanpa memperhatikan apakah perlawanan mereka ditujukan kepada pemimpin adil atau pemimpin zalim, terlepas apakah aksi mereka didasari penafsiran agama yang salah atau semata-mata karena niat duniawi, tetap saja aksi mereka secara tegas disebut sebagai pemberontakan atau aksi terorisme. Selama mereka melakukan perlawanan bersenjata dan melawan pemerintahan Muslim, maka selama itu pula pemerintah harus melakukan tindakan militer untuk melawan mereka (ISIS), sampai mereka menyerah, kembali mengakui kedaulatan negara, menghentikan semua aktivitas terornya, mengambil sumpah untuk hidup secara damai sebagai warga negara, mendukung cara-cara konstitusional dan demokratis untuk mewujudkan tujuan-tujuan yang hendak mereka capai.

\section{Daftar Pustaka}

Aini, Badr Al-Din, Al-Umdah Al-Qari Syarh Shahih Al-Bukhari, Beirut: Dar Ihya Al-Turats AlArabi, tt.

Akaha, Abdul Zulfidar, Terorisme Konspirasi Anti Islam, Jakarta: Pustaka Al-Kautsar, 2005. Al-Bani, Muhammad Nashir Al-Din. Al-Ahaïis Al-Shahīhah. Riyadh: Dra Al-Wathan, 1999. Al-Khalā, HR., Al-Sunan, tt.

Al-Syāfi'i, Muhammad bin Idris, Al-Umm, Beirut: Dār Al-kutub Al-Ilmiyyah, tt.

Bukhari, Abu Abdi Allah Muhammad bin Ismail bin Ibrahim bin Mughirah, Al-Jami AlShahih, Beirut: Dar Ibnu Katsir, 1987.

Fauzan, Shalih bin Fauzan, Al-Jihad Dhawabithuhu Al-Syar"iyyah, tt. Hanifah, Abū, Al-Figh Al-Al-Absath, (Zāhid Al-Kausar dalam Majmū Al-Aqidah wa 'lim Alkalām, tt.

Husain, Fahd, Al-Fatawa Al-Syar'iyyah Al-Qadiyyah Al-Syar'Iyyah, tt. Muladi, Demokrasi HAM dan Reformasi Hukum di Indonesia, Jakarta: RajaGrafindo, 2002. Mustofa, Muhammad, "Memahami Terorisme: Suatu Perspektif Kriminolog”, Jurnal Kriminologi Indonesia, Jakarta: FISIP UI, 2002. 
Sahrūn, Al-Mudawwamah Al-Kubrā, tt.

Salenda, Kasjim, "Terorisme dalam Perspektif Hukum Islam”, Ulumuna, Volume XIII, Nomor 1, Juni 2009.

Ul-Qadri, Muhammad Tahir, Fatwa Tentang Terorisme dan Bom Bunuh Diri, Jakarta: Minhaj-Ul-Quran, 2010. 